\title{
The Degree of Practicing Organizational Justice by Teachers of Learning Disabilities in English Language from their Point of View
}

\author{
Mohammad Ahmad Saleem Khasawneh ${ }^{1}$ \\ Corresponding Email: mkhasawneh@kku.edu.sa \\ ${ }^{1}$ Assistant Professor, Special Education Department, King Khalid University, Saudi Arabia \\ Received: July 15, 2021 \\ Revised: August 26, 2021 \\ Accepted: September 7, 2021
}

\begin{abstract}
The study aimed at identifying the degree of practicing organizational justice by teachers of learning disabilities in English language from their point of view. The study used the descriptive approach and developed a questionnaire, which was administered to a sample of (30) teachers of LDs in English language in the Irbid governorate. The questionnaire was used to collect data that included demographic information about the respondent and to measure the use of organizational justice among teachers of LDs in English language. The validity of the study instrument was verified by presenting it to specialized judges, and their reliability was verified using the test and re-test method. The results of the study showed a high practice of organizational justice among teachers of LDs in English language in general and in all the dimensions of the instrument. In light of these results, the study recommended increasing the practice of organizational justice in educational institutions to increase teachers' performance and holding more training on the topic.
\end{abstract}

Keywords: LDs Teachers, English Language, Organizational Justice

\section{Introduction}

Akram et al (2020) explained that organizational justice as a value, content, and variable has its implications in organizational influence. It is one of the variables affecting the organizational behavior of the workers in the organization, based on the fact that organizational justice shows how the members of the organization can judge the fairness of the organization in its dealings with them at the job and human levels. Kottrabac (2003) argued that the studies conducted in this field indicated the existence of strong correlations between organizational justice on the one hand and between job satisfaction, organizational commitment, and organizational loyalty on the other hand.

Greenberg \& Cropanzano (2001) defined organizational justice as the awareness of individuals of the state of fairness in the treatment they receive from organizations. Jameel et al (2020) mentioned that the individual's perception of justice is affected by social and religious values. One of the most important factors affecting the relationship between the teacher and students is the extent to which one of the parties realizes the values of justice in that relationship. Hence came the interest in explaining the behavior resulting from the mentioned relationship and predicting it in work situations and personal exchange relationships. Organizational justice is important because it is an influencing variable in the operations and functions of public administration. It is viewed as one of the organizational variables related to the efficiency of the job performance of employees in organizations, as well as the performance of the organizations themselves (Zayed, 2000).

Therefore, this study came to investigate the level of organizational justice among teachers of learning disabilities in English language, as they are an important part of the educational 
institution, and due to the absence of previous studies on this subject. The study attempted to measure the levels of organizational justice from the teachers' point of view.

To achieve the objectives of this research, the study attempted to answer the following question:

-What is the level of practicing organizational justice by teachers of LDs in English language in Irbid from their point of view?

This study explored the opinions of an important group in educational institutions of the concept of organizational justice and its importance in work organizations. The efficiency and effectiveness of the human element depend on the amount of a healthy organizational environment available to it that takes into account its considerations, feelings, and needs. The availability of a sound organizational climate helps the development of the administrative organization, increases its effectiveness, improves the level of performance of its members, and reduces its operating costs. It is hoped that the results of this study will benefit teachers in the Jordanian Ministry of Education by identifying the degree of their practice of organizational justice. It is also hoped that this study will add knowledge to the Arabic literature on this topic, and be a starting point for researchers and those interested in organizational behavior variables in different business organizations to conduct more studies and research in this field.

However, this study had several limitations. The study was limited to teachers of LDs in English language in Irbid Governorate during the academic year (2019-2020). The results of this study are determined by the degree of validity and reliability of the instruments and the sincerity of the responses of the sample members to the questionnaire.

\section{Literature Review}

Social justice is one of the important issues that occupied the minds of many thinkers throughout the ages and was dealt with by most intellectual and educational doctrines. Thinkers and moral philosophers have agreed that justice is one of the basic values of social life, if not in the first place (Novitasari et al, 2020). It is a consensus that has remained constant despite the many variables that human life has known throughout the ages, and there is no explanation for this except that the concept of justice is rooted in human instinct, closely related to all moral values, such as equality and truth. If society is built on collaboration, justice, and interaction between its members, each of them had legitimate rights in light of the rules and norms set by society to determine those rights and settle disputes about them. The realization of the principle of justice is what achieves balance and parity and the provision of rights in the arena of social life (Al-Qatawneh, 2003).

Greenberg \& Cropanzano (2001) defined organizational justice as the individuals' awareness of the state of fairness in the treatment they received by organizations. Al-Assaf (2005) defined the degree of organizational justice as the ratio of inputs (effort at work) to outputs (salary or income or recognition and appreciation) compared to others. Hassan (2002) defined the theory of justice as the belief of an individual that he is treated fairly compared to others.

Al-Maaytah (2005) explained that organizational justice is a fair procedure and that it is a requirement for all people, and a good recipe, and a legitimate demand since ancient times, as it is viewed with a value and ideological perspective. Sultan (2006) indicated that organizational justice is an important value and a human feeling and awareness that members of the organization feel within the framework of psychological and administrative evaluations, through comparisons between the mutual values obtained by the members and the management of the organization. Thus, organizational justice is an emotionally valuable sense of direction towards completeness with institutional justice, which workers in the administrative organization are reassured of in their equal rights and job gains despite their differences in their varying level of awareness of these comparisons (Silitonga et al, 2020). 


\section{Previous Studies}

Organizational justice is gaining increasing attention for many researchers and those interested in the field of business administration and public administration because of the interest and close look at this concept. It is one of the important variables that affect the efficiency and performance of employees in organizations and the effectiveness and efficiency of these institutions, which can explain many influences in the organizational behavior of workers and institutional performance.

Al-Mahawsh (2021) showed that the phenomenon of justice is one of the important phenomena in management and explored the low levels of organizational performance of individuals and institutions. The study used the descriptive approach. The viewpoints differed in the dimensions of the organizational relationship, some of whom described it as a variable in one dimension, such as procedural justice. Those who dealt with it reflect two dimensions, which are procedural and distributive justice. Some views considered the variable that reflects three dimensions of procedural, distributive, and transactional justice.

Shamma \& Shurman (2018) investigated the level of organizational justice among school principals inside the Green Line according to the organizational commitment of teachers. The study used the descriptive approach and built a questionnaire, which was administered to 354 teachers. The findings showed high levels of organizational justice among teachers. The study also showed that the high commitment from teachers increases organizational justice.

Al-Ali \& Matlaa (2016) investigated the standards of organizational fairness prevailing in the faculties of the Public Authority for Applied Education and Training. The study used a field study as a methodology for data analysis. The findings revealed the low availability of regulatory equity standards There was a positive, statistically insignificant correlation between organizational equity standards combined and academic performance standards has also been found, although their degree of relevance is relatively weak. The study concluded that increasing the effectiveness of the role of the Faculty Members Association has a statistically significant direct link in consolidating the combined organizational equity standards.

Al-Qatawneh \& Khalifat (2015) explored the relationship between leaving work and organizational justice among teachers in private schools in Jordan. The study used the descriptive approach and developed a questionnaire that was distributed to a sample of 480 female and male teachers. The results showed that the organizational justice according to the sample was medium. The findings also showed a relationship between the level of organizational justice and leaving work by teachers of private schools.

Saidia \& Abu Al-Naga (2009) explored the relationship between organizational citizenship behavior and organizational justice among basic education teachers in Oman. The study used the descriptive approach and developed a questionnaire, which was distributed to 317 teachers. The results showed a high level of organizational citizenship behavior and organizational justice among the teachers. The views of teachers did not differ according to the gender variable but differ according to their experience and academic qualifications.

Sultan (2006) identified the level of organizational justice among department heads in public Jordanian universities and its relationship to job satisfaction and organizational loyalty among faculty members. The study sample consisted of (450) faculty members. The results of the study showed that the level of organizational justice among heads of the academic departments was high. There was a significant difference in the level of faculty members' feeling of job satisfaction and organizational loyalty, and it was found that there was a positive, direct, statistically significant relationship between the practice of justice by the heads of academic departments and job satisfaction and organizational loyalty. 
Coloski (2003) investigated the relationship between organizational justice (distributive, procedural, and interactive) and the volume of conflict and violence among students in middle schools in the United States of America. The study instrument included (29) items distributed on three dimensions of organizational justice. The results showed a correlation between the student's sense of injustice and the size of conflict and violence among students. The results also revealed the presence of statistically significant differences in students' concept of organizational justice due to gender and grade.

\section{Methods}

The researcher used the descriptive-analytical and correlational methods in this study. The study population consisted of all (30) teachers of LDs in English language in the Irbid governorate. The study sample consisted of (20) male and female teachers.

\section{Instrument of the Study}

The instrument of the study was a questionnaire on the levels of organizational justice. The questionnaire was used to find out the degree of practicing organizational justice by teachers of LDs in English language. The questionnaire included (20) statements, divided into (3) areas (evaluative justice, distributive justice, and procedural justice).

To ensure the validity of the instrument, the linguistic integrity of the statements of the organizational justice questionnaire was checked after presenting it to several specialists. The validity of the instrument was also verified using the Content Validity method. The questionnaire was presented to (20) specialized judges. The judges expressed their observations and opinions about the degree of validity of the statements, their suitability for measuring the degree of organizational justice, the degree of suitability of each statement to the field in which it was placed, adding any paragraph they deem appropriate, and deleting any paragraph they deem fit.

To ensure the reliability of the organizational justice questionnaire, the test-retest method was used. The organizational justice questionnaire was distributed to an initial sample of (15) individuals. The test was applied again on the same sample two weeks later. The reliability coefficient was extracted for each type of organizational justice, and the scale as a whole, using the Pearson correlation coefficient. To find out the internal consistency of the statements, Cronbach alpha was used as shown in Table (1).

Table 1. Pearson and Cronbach's alpha correlation coefficient for organizational justice questionnaire

\begin{tabular}{|l|l|c|c|}
\hline Instrument & Dimension & $\begin{array}{c}\text { Pearson correlation } \\
\text { coefficient }\end{array}$ & $\begin{array}{c}\text { Cronbach's alpha } \\
\text { correlation coefficient }\end{array}$ \\
\hline \multirow{3}{*}{$\begin{array}{l}\text { Organization } \\
\text { al Justice }\end{array}$} & Evaluative Justice & 0.92 & 0.93 \\
\cline { 2 - 4 } & Distributive Justice & 0.80 & 0.93 \\
\cline { 2 - 4 } & Procedural Justice & 0.90 & 0.93 \\
\cline { 2 - 4 } & Total & 0.95 & 0.97 \\
\hline
\end{tabular}

To answer the study question, "What is the degree of practicing organizational justice by teachers of LDs in English language from their point of view?" the mean scores and standard deviations of the dimensions and statements of the organizational justice questionnaire and their total score were calculated. The ranks were also calculated and their scores were determined according to the previous standard and arranged in descending order according to the highest mean score for the statement. It was found that the degree of practicing organizational justice 
by teachers of LDs in English language from their point of view was high as shown in Table (2).

Table 2. The mean scores and standard deviations of the degree of practicing teachers of LDs in English from their point of view

\begin{tabular}{|c|c|c|c|c|}
\hline Dimension & Mean score & $\begin{array}{c}\text { Standard } \\
\text { deviation }\end{array}$ & Rank & level \\
\hline evaluative justice & 3.91 & 0.82 & 2 & High \\
\hline interactive justice & 3.79 & 0.84 & 3 & High \\
\hline procedural justice & 3.74 & 0.78 & 4 & High \\
\hline Total & 3.84 & 0.78 & & High \\
\hline
\end{tabular}

Table (2) shows that the total mean score of the degree of practicing organizational justice by teachers of LDs in English language from their point of view was (3.84) degrees out of (5) degrees, and a standard deviation (0.78), which is considered a high degree. Table (2) shows that the procedural justice dimension came in the first place with a mean score of (3.91) degrees and a standard deviation of (0.82). The distributive justice came last with a mean score of (3.74) and a standard deviation of (0.78), which is a high rank.

For further clarification, the mean scores and standard deviations were calculated for the statements of each dimension of organizational justice separately, and the following is a presentation of the results.

\section{First: Procedural Justice}

The mean scores and standard deviations were calculated for all statements for the procedural justice, and they were arranged in descending order according to the highest mean score as shown in Table (3).

Table 3. The mean score and standard deviations for the procedural justice dimension

\begin{tabular}{|c|l|c|c|c|c|}
\hline No. & \multicolumn{1}{|c|}{ Statements of the procedural justice } & $\begin{array}{c}\text { Mean } \\
\text { score }\end{array}$ & $\begin{array}{c}\text { Standard } \\
\text { deviation }\end{array}$ & Rank & level \\
\hline 20 & $\begin{array}{l}\text { The LDs in English language teacher explains } \\
\text { his impressions of the workflow. }\end{array}$ & 4.05 & 0.99 & 1 & High \\
\hline 16 & $\begin{array}{l}\text { The teacher explains decisions and provides } \\
\text { staff with information about them upon } \\
\text { request. }\end{array}$ & 4.01 & 0.94 & 2 & High \\
\hline 188 & $\begin{array}{l}\text { The teacher explains to all students their } \\
\text { rights and duties. }\end{array}$ & 3.95 & 1.05 & 3 & High \\
\hline 17 & $\begin{array}{l}\text { The teacher holds students accountable for } \\
\text { violating instructions fairly. }\end{array}$ & 3.94 & 0.96 & 4 & High \\
\hline 15 & $\begin{array}{l}\text { The teacher applies all work decisions } \\
\text { consistently }\end{array}$ & 3.88 & 0.97 & 5 & High \\
\hline 14 & $\begin{array}{l}\text { The teacher makes business decisions without } \\
\text { bias. }\end{array}$ & 3.89 & 1.08 & 6 & High \\
\hline 12 & $\begin{array}{l}\text { The teacher gathers accurate and complete } \\
\text { information before making work-related } \\
\text { decisions. }\end{array}$ & 3.87 & 1.05 & 6 & High \\
\hline & \multicolumn{1}{|c|}{ Total } & 3.91 & 0.82 & - & High \\
\hline
\end{tabular}




\section{Second: evaluative justice}

The mean scores and standard deviations were calculated for all statements for the evaluative justice dimension, and they were arranged in descending order according to the highest mean score as shown in Table (4).

Table 4. The mean score and standard deviations for the evaluative justice dimension

\begin{tabular}{|c|l|c|c|c|}
\hline No. & \multicolumn{1}{|c|}{ Statements of the Evaluative Justice } & $\begin{array}{c}\text { Mean } \\
\text { score }\end{array}$ & $\begin{array}{c}\text { Standard } \\
\text { deviation }\end{array}$ & Rank \\
\hline 7 & $\begin{array}{l}\text { The teacher allows students to complain } \\
\text { about the results of an unfair assessment. }\end{array}$ & 3.92 & 1.02 & High \\
\hline 2 & $\begin{array}{l}\text { The teacher informs the students of the } \\
\text { assessment criteria in advance }\end{array}$ & 3.85 & 1.01 & High \\
\hline 1 & $\begin{array}{l}\text { The performance evaluation process is not } \\
\text { affected by personal relationships with } \\
\text { students. }\end{array}$ & 3.84 & 1.07 & High \\
\hline 3 & $\begin{array}{l}\text { The teacher uses clear and previously } \\
\text { known criteria to assess students. }\end{array}$ & 3.76 & 1.04 & High \\
\hline 4 & $\begin{array}{l}\text { The training programs are based on the } \\
\text { evaluation of student's performance by the } \\
\text { teacher }\end{array}$ & 3.76 & 1.07 & High \\
\hline 6 & $\begin{array}{l}\text { Assessment of the teacher helps students } \\
\text { to know the strengths and weaknesses in } \\
\text { their performance. }\end{array}$ & 3.68 & 1.06 & Mediu \\
\hline 5 & $\begin{array}{l}\text { The teacher applies performance } \\
\text { evaluation criteria with a high degree of } \\
\text { fairness. }\end{array}$ & 3.66 & 1.04 & High \\
\hline & Total & 3.79 & 0.84 & \\
\hline
\end{tabular}

\section{Third: Distributive Justice}

The means and standard deviations were calculated for all items after interactive justice, and they were arranged in descending order according to the highest mean score as shown in Table (5).

Table 5. The mean score and standard deviations for the distributive justice dimension

\begin{tabular}{|c|c|c|c|c|}
\hline No. & Statements of the distributive justice & $\begin{array}{c}\text { Mean } \\
\text { score }\end{array}$ & $\begin{array}{c}\text { Standard } \\
\text { deviation }\end{array}$ & Rank \\
\hline 25 & I feel the rewards I get are fair. & 3.90 & 0.95 & High \\
\hline 26 & $\begin{array}{c}\text { The teacher distributes the work } \\
\text { among the students fairly. }\end{array}$ & 3.88 & 1.02 & High \\
\hline 2 & $\begin{array}{c}\text { The teacher delegates some of his } \\
\text { powers to the students. }\end{array}$ & 3.81 & 1.01 & High \\
\hline 10 & I think the level of wages I get is fair. & 3.76 & 1.05 & High \\
\hline 18 & $\begin{array}{c}\text { I think my work schedule fits in with } \\
\text { my time. }\end{array}$ & 3.41 & 1.16 & $\begin{array}{c}\text { Mediu } \\
\text { m }\end{array}$ \\
\hline 1 & I think my workload is just right. & 3.24 & 1.28 & $\begin{array}{c}\text { Mediu } \\
\text { m }\end{array}$ \\
\hline & Total & 3.74 & 0.78 & High \\
\hline
\end{tabular}

The results of this study showed that the degree of practicing organizational justice among teachers of LDs in English language, in general, was high. The total mean score value was (3.83) out of (5) degrees. The researcher believes that the reason for this high level of the degree 
of the practice of organizational justice by teachers of LDs English language may be due to the efforts made by the Ministry of Education in preparing the teacher and making a qualitative shift in administrative methods in thought, behavior, and practice. These efforts helped in achieving the objectives of the educational process, which was one of the objectives of the educational development conferences held in the past years

\section{Recommendations}

Informing teachers, administrators, and employees of the Ministry of Education in the center and in the field the results of the study as feedback on the level of organizational justice, which generates achievement motivation and enhances confidence in the organizational culture of the Jordanian Ministry of Education. Conducting seminars to demonstrate the importance of organizational justice and its impact on the level of performance and the organizational climate in general. Conducting future studies on these variables in the education directorates in the field and on other variables related to organizational behavior such as motivation, job satisfaction, and job commitment.

\section{Acknowledgments}

The authors extend their appreciation to the Deanship of Scientific Research at King Khalid University for funding this work through Big Research Groups under grant number (RGP.2 /103/42)

\section{References}

Akram, T., Lei, S., Haider, M. J., \& Hussain, S. T. (2020). The impact of organizational justice on employee innovative work behavior: Mediating role of knowledge sharing. Journal of Innovation \& Knowledge, 5(2), 117-129.

Al-Ali, A. A. \& Matlaa, M. K. (2016). The reality of organizational justice in academic institutions: an exploratory study. Journal of Economics and Human Development: University of Lounici Ali Blida 2- Economic and Human Development Laboratory, 15, 105 - 159. http://search.mandumah.com/Record/782449

Al-Assaf, L. M. (2005). The Sources of the Authority of Public Secondary School Principals in Jordan and its Relationship to the Control Center and Achievement Motivation for Teachers of those Schools. An unpublished Ph.D. thesis, Amman Arab University for Graduate Studies: Amman, Jordan.

Al-Mahawsh, N. A. (2021). Organizational justice in the context of school administration. Reading and Knowledge Magazine: Ain Shams University - College of Education Egyptian Society for Reading and Knowledge, 231, pp 171 - 190. http://search.mandumah.com/Record/1119788

Al-Qatawneh, A. T. \& Khalifat, A. S. M. (2015). The Organizational Justice and its Relationship with the Intention to Leave work among the Teachers of the Private Schools in the Governorates of the South of Jordan (unpublished master's thesis). Mutah University, Karak. http://search.mandumah.com/Record/785974

Al-Qatawneh, N. A. (2003). The effect of organizational justice on organizational loyalty. Unpublished Master's Thesis, Mutah University: Karak.

Al-Maaytah, A. A. G. (2005). The degree to which public secondary school principals in Jordan practice organizational justice and its relationship to the organizational citizenship behavior of their teachers. An unpublished Ph.D. thesis, Amman Arab University: Amman, Jordan.

Coloski, M. (2003). An Instrument to Measure Perceptions of Organizational Justice of Middle Schools, Dissertation Abstract International, 63(8), P.27-55. 
Green berg, J, and cropan zano, R. (2001). Advances in Organizational Justice. Stand ford University Press in California.

Hassan, R. (2002). Contemporary Organizational Behavior. Alexandria, University House.

Jameel, A. S., Mahmood, Y. N., \& J Jwmaa, S. (2020). Organizational justice and organizational commitment among secondary school teachers.

Kottraba, C. (2003). "The relationship between Organizational Justice, employee absenteeism and role stress", Dissertation Abstract International, 64(2), 990

Novitasari, D., Asbari, M., Wijaya, M. R., \& Yuwono, T. (2020). Effect of Organizational Justice on Organizational Commitment: Mediating Role of Intrinsic and Extrinsic Satisfaction. International Journal of Science and Management Studies (IJSMS), 3(3), 96-112.

Saidia, D. K. H. \& Abu Al-Naga, T. A. M. (2009). Organizational Citizenship Behavior And Its Relationship To Organizational Justice To The Basic Education Teachers In The Sultanate Of Oman From The Point Of View. (unpublished master's thesis). Mutah University, Karak. http://search.mandumah.com/Record/785650

Shamma, F. M. \& Shurman, M. M. (2018). Organizational justice among school principals within the Green Line and its relationship with organizational Commitment of Teachers from their point of view. (unpublished Ph.D. thesis). Yarmouk University, Irbid. http://search.mandumah.com/Record/953884

Silitonga, N., Novitasari, D., Sutardi, D., Sopa, A., Asbari, M., Yulia, Y., ... \& Fauji, A. (2020). The Relationship Oftransformational Leadership, Organizational Justice And Organizational Commitment: A Mediation Effect Of Job Satisfaction. Journal of Critical Reviews, 7(19), 89-108.

Sultan, S. A. (2006). Organizational justice among the heads of academic departments in Jordanian universities and its relationship to job satisfaction and organizational loyalty to faculty members. unpublished doctoral thesis, Amman Arab University: Amman, Jordan.

Zayed, A. M. (2000). Analysis of the relationship between job performance control methods and workers' sense of organizational justice. The Arab Journal of Administrative Sciences, 20(12), pp. 269-298 